\title{
Characterization and Identification of Plant Growth Promoting Traits of a Rhizobacteria: Pantoea Agglomerans 20-19
}

\author{
Kahkahi RE ${ }^{1 *}$, Moustaine $\mathbf{M}^{2}$, Mouhajir $\mathbf{A}^{1}$, \\ Zouhair R', Chitt $\mathbf{M A}^{\mathbf{3}}$ and Errakhi $\mathbf{R}^{\mathbf{4}}$ \\ ${ }^{1}$ Department of Biology, University Moulay Ismail, \\ Zitoune, Meknes, Morocco \\ ${ }^{2}$ Laboratory of Botany and Plant Protection, University \\ Ibn Tofail, Kenitra, Morocco \\ ${ }^{3}$ El Bassatine Domaine, Meknes, Morocco \\ ${ }^{4}$ Eurofins Agroscience Services, Meknes, Morocco \\ *Corresponding author: Rahal El Kahkahi, \\ Department of Biology, University Moulay Ismail, \\ Laboratory of Plant Biotechnology and Molecular Biology, \\ Faculty of Science, PO-Box 11201, Zitoune, Meknes \\ 50000, Morocco
}

Received: June 28, 2021; Accepted: July 26, 2021; Published: August 02, 2021

\begin{abstract}
Plant Growth Promoting Rhizobacteria (PGPR) are known to influence positively plant growth by various direct or indirect mechanisms. The objective of this study was to characterize and identified a bacterium was isolated from the wheat rhizosphere of an semi arid area Meknes (Morocco). The studied strain possess several PGPR trais such as nitrogen fixation ability, phosphate solubilization, production of auxins and Ammonia production. Based on their $16 \mathrm{~S}$ rDNA sequences, the strain were identified as Pantoea agglomerans 2019. This Pantoea agglomerans $20-19$ is capable of IAA, ammonia production, nitrogen fixation and solubilization phosphorus. These results showed that Pantoea agglomerans 20-19 with its PGPR traits could consitute a good biofertilizer in semi arid area.
\end{abstract}

Keywords: Pantoea agglomerans; PGPR; IAA; Ammonia; Nitrogen fixation and phosphorus solubilization

\section{Introduction}

Indiscriminate use of chemical fertilizer and pesticides over the last few decades has not only resulted in the contamination of environment, but also reduced soil fertility. However, the fertilizers overuse could lead to serious soil acidification, nutritional imbalance and deterioration of the rhizosphere micro-ecological environment, further increased the activity of heavy metal ions in soil [1]. Due to the adverse effects of chemical fertilzers on the environment and ecology, nowadays bio-fertilizers (Plant growth promoting rhizobacteria) are being projected as an essential component of organic farming to play a key role in the maintenance of long-term soil fertility as well as sustainability [2].

The rhizosphere microbiome harbors Plant Growth Promoting Rhizobacteria (PGPR), nitrogen fixing symbionts, endophytes, mycorrhizal fungi, biocontrol microorganisms [3-5]. PGPR are a group of bacteria that colonize plant roots and proivde beneficial effects on plant growth and development. PGPR have direct or indirect effects on plant growth promotion and improved crop yield. Direct effects of PGPR include providing plants with fixed nitrogen and phytohormones, increasing the availability of nitrogen, soluble phosphate and minerals in the soil and control or inhibition of the activity of plant pathogens [6-8]. Some PGPR are also responsible for promoting growth indirectly by eliciting induced systemic resistance [9]. Some bacteria such as Klebsiella sp. D5A showed the high plant growth promoting activity on the glycophytic crop in saline-alkaline soils $[10,11]$. Likewise, many studies have been pulished on beneficial effects of bacterial application on growth of Wheat under salt stress [12-15]. Various bacterial genera like Azospirillium, Arthrobacter, Azotobacter, Azoarcus, Serratia, Bacillus, Pseudomonas, Enterobacter, Rhizobium, Gluconacetobacter, Erwinia, Acinetobacter, Burkholderia, Beijerinckia, and Klebsiella are well known for their
PGPR activities [16-19]. These microoragnisms act as promoters of plant growth vi the production of amino acids, Indole Acetic Acid (IAA), gibberellins and other polyamines, improving root growth and, consequently, increasing water and nutrient absorption bt the plants and generating rhizobia-plant interaction sites [20]. Among other benefits, PGPR are also able to solubilize phosphates, produce siderophores, fix $\mathrm{N}_{2}$ and mitigate biotic and abiotic stresses [21]. In the sense, the co-inoculation of microorganisms with different function can be considred an economically viable and environmentally sustainable strategy to improve plant performance [22,23].

The objective of this study was characterize by different methods includes: morphology, physiology and biochemistry and molecular identification of strain of Pantoea agglomerans 20-19, plant growth promoting rhizobacteria in the region Meknes of Morocco.

\section{Materials and Methods}

\section{Bacterial strains and growth conditions}

The bacterium Pantoea agglomerans belongs to the collection of the of Laboratory of Plant Biotechnology and Molecular Biology, Department of Biology, Faculty of Science, University Moulay Ismail (Morocco). This strain was grown at $30^{\circ} \mathrm{C}$ on LPGA medium (5g/l Yeast extract, 5g/l Peptone, 10g/l Glucose and 18g/l Agar).

\section{Identification of Pantoea 20-19}

Genomic DNA was extracted from the bacterial isolate using the Gen Elute Mammalian Genomic miniprep Kit (Sigma-Aldrich, USA). Polymerase chain reaction was used to amplify 500pd fragments using primers Fd1(CAGAGTTTGATCCTGGCTCAG) and RP2 (AGAGTTTGATCCTGGCTCAG). The amplification of 16S rDNA was conducted following the procedure described by El kahkahi et al. 2019 and the amplified DNA products were sequenced at CNRST Laboratory (National Centre for Scientific Research and Technology
Austin J Microbiol - Volume 6 Issue 1 - 2021

ISSN: 2471-0296 | www.austinpublishinggroup.com

Kahkahi et al. @ All rights are reserved
Citation: Kahkahi RE, Moustaine M, Mouhajir A, Zouhair R, Chitt MA and Errakhi R. Characterization and Identification of Plant Growth Promoting Traits of a Rhizobacteria: Pantoea Agglomerans 20-19. Austin J Microbiol. 2021; 6(1): 1032. 
Table 1: Antimicrobial agents and concentrations tested.

\begin{tabular}{|l|c|c|}
\hline \multicolumn{1}{|c|}{ Antibiotics } & Code & Concentration disc $(\boldsymbol{\mu g})$ \\
\hline Amoxycillin & AML & 25 \\
\hline Amoxycillin/Clavulanic acid & AMC & 30 \\
\hline Ticarcillin & TIC & 75 \\
\hline Imipenem & IMP & 10 \\
\hline Cefadroxil & CFR & 30 \\
\hline Cefoxitin & FOX & 30 \\
\hline Ceftriaxone & CRO & 30 \\
\hline Cefixime & CFM & 5 \\
\hline Gentamicin & CN & 15 \\
\hline Amikacin & AK & 30 \\
\hline Colistin & CT & 50 \\
\hline Ciprofloxacin & CIP & 10 \\
\hline Nadilixid acid & NA & 30 \\
\hline Trimethoprim-sulfamethoxazole & SXT & 25 \\
\hline Fosfomycin & FOS & 50 \\
\hline
\end{tabular}

in Rabat, Morocco).

\section{Morphology, physiology and biochemistry characterization of Pantoea 20-19}

Pantoea 20-19 was characterized and tentatively identified on the basis of their biochemical characteristics according to Bergey's manual of determinative bacteriology [24]. These tests were followed by identification using a biochemical API20E (BioMerieux) and ABIS online software.

\section{Measurement of promoting growth plant activities}

Qualitative estimation of phosphate solubilization: The isolate of Pantoea agglomerans was screened qualitatively for phosphate solubilization on the PVK medium [25]. The phosphate solubilization ability was analyzed by measure of the diameter of a clear halo zone around colonies after incubation at $30^{\circ} \mathrm{C}$ for seven days. The phosphate solubilization index (PSI). was calculated by using the following formula [26]. (PSI=[(colony diameter + Halo diameter $) /$ Colony diameter].

Determination of indole acetic acid production (IAA): IAA production by Pantoea agglomerans was estimated with the method of Loper and Scroth [27]. 500 $\mu \mathrm{l}$ of bacterial culture (24h old) was inoculated in $50 \mathrm{ml}$ of nutrient broth added with $0.1 \%$ L-tryptophan and incubated at $30^{\circ} \mathrm{C}$ for 2 days in the dark. After incubation, the bacterial culture were centrifuged at $10000 \mathrm{rpm}$ for $10 \mathrm{~min}$. Salkowski ragent $(4 \mathrm{ml})$ was added to one $\mathrm{ml}$ of collected supernatant and after 30 min incubation pink color developed which indicated production of IAA. To quantify IAA, absorbance was taken at $535 \mathrm{~nm}$ by using UV/Visible spectrophotometer. The IAA concentration was estimated with a standard curve of IAA.

Determination of ammonia production: The production of ammonia was determined according the Cappucina and Sherman Table 2: Identification of strain $20-19$ by 16 S rDNA sequencing.

\begin{tabular}{|c|c|c|c|c|}
\hline Strain & Number of base pairs & Closest relative sepecies & Similarity (\%) & Accession number in Gen Bank (NCBI) of the Strain \\
\hline $20-19$ & 1271 & Pantoea agglomerans & $97 \%$ & GQ478021 \\
\hline
\end{tabular}
incubated at $30^{\circ} \mathrm{C}$ of 2 days. After that, Nessler's reagent $(0.5 \mathrm{ml})$ was added in each tube and development of yellow to brown color indicated ammonia production.

Nitrogen fixation: The qualitative estimation of Nitrogen fixation was conducted using the method described by Rajasankar and Ramalingam [29]. A nitrogen free semi-solid medium was used with the following composition: $5 \mathrm{~g}$ Malic acid, $0.5 \mathrm{~g} \mathrm{~K}_{2} \mathrm{HPO}_{4}, 0.2 \mathrm{~g} \mathrm{MgSO}_{4}$ $7 \mathrm{H}_{2} \mathrm{O}, 0.1 \mathrm{~g} \mathrm{NaCl}, 0.02 \mathrm{~g} \mathrm{CaCl}_{2}$, and $0.5 \%$ bromothymol blue in $0.2 \mathrm{~N}$ $\mathrm{KOH} 2 \mathrm{ml}, 4 \mathrm{ml}$ of $1.64 \%$ Fe-EDTA solution and $2 \mathrm{~g}$ agar, distilled water (1liter) was then added for a final $\mathrm{pH}$ of 7 . The cultures were then incubated at $30^{\circ} \mathrm{C}$ for 5 days and the formation of a pellicle at the sub surface level was considered to be a positive test for $\mathrm{N}$ fixation.

\section{Antibiotic sensitivity assay}

Antibiotic sensitivity or resistance of Pantoea agglomerans was carried out following to the Clinical and Laboratory Standard Institute (CLSI). Fifteen antibiotics (Oxoid) were chosen for the study (Table 1). The sowing on plate was made of each strain on Muller-Hinton agar (MHA) media plates by using swab stick. Antibiotic discs were placed on MHA plates. The plates were incubated at $30^{\circ} \mathrm{C}$ for $24 \mathrm{~h}$. The inhibition zone was measured in millimetres $(\mathrm{mm})$ surrounding the antibiotics discs.

\section{Results}

The bacterial isolate 20-19 was isolate from the rhizosphere of Wheat (Triticum aestivum). Microscopic observation revealed that the isolate is a Gram negative rod shaped bacterium. Molecular analysis based on 16S rDNA gene homology identified the 20-19 as Pantoea agglomerans with $97 \%$ similariy with the reporeted gene sequence (Table 2).

Biochemical tests such as oxidase test, catalase, carbohydrate utilization, citrate utilization etc. were carried out for phenotypic identification of strain. Biochemical characterization of strain and enzymatic activities of the strain were tabulated in Table 3. Briefly, the strain were rod shaped were positive for urea and ONPG. The strain Pantoea agglomerans degraded some carbon sources such as Glucose, Mannitol, Rhamnose and Saccharose. Selected strain was Gram negative rod, catalase positive, oxidase negative, mobile, fermenting glucose without gas production. The strain were characterized by biochemical attributes and were identified as Pantoae agglommerans on the basis of ABIS online software (Table 3 ).

Plant growth promoting traits are described in Table 4. Pantoea agglomerans is capable of synthesize IAA, ammonia, Nitrogen fixation and phosphorus solubilization.

The antibiotic susceptibility results of Pantoea agglomerans is shown in Table 5. Pantoea agglomerans was highly sensitive to Amoxycillin, Amoxycillin/Clavulanic acid, Ticarcillin, Imipenem, Cefadroxil, Cefoxitin, Gentamicin, Amikacin, Colistin, Ciprofloxacin, Nadilixid acid and Trimethoprim-sulfamethoxazole. This species showed low resistance to Ceftriaxone, Cefixime and Fosfomycin.
[28]. The bacterial strains were grown in $10 \mathrm{ml}$ of peptone water and 
Table 3: Biochemical characterization of Panoea agglomerans 20-19.

\begin{tabular}{|c|c|c|c|}
\hline & $\begin{array}{c}\text { P. agglomerans isolate of } \\
\text { this study }\end{array}$ & $\begin{array}{l}\text { Characteristics of } P \text {. agglomerans Im2 as } \\
\text { reported by Silini-Cherif et al. } 2012\end{array}$ & $\begin{array}{l}\text { Characteristics of } P \text {. agglomerans as } \\
\text { reported by Loch and Faisal (2007) }\end{array}$ \\
\hline Gram Strain & - & - & - \\
\hline Production of $\mathrm{H}_{2} \mathrm{~S}$ & - & - & - \\
\hline Simmons Citrate & + & + & + \\
\hline Production of Indole & - & - & - \\
\hline Voges-Proskauer & - & + & + \\
\hline Nitrate Reduction & + & + & + \\
\hline Lysine Decarboxylase & - & - & - \\
\hline Ornithine Decarboxylase & - & - & - \\
\hline Arginine Dihydrolase & + & - & - \\
\hline Catalase & - & + & + \\
\hline Oxidase & + & - & - \\
\hline ONPG & - & + & - \\
\hline Phenylalanine Deaminase & + & - & - \\
\hline Urease & + & - & - \\
\hline Motility & + & + & $\mathrm{Nd}$ \\
\hline \multicolumn{4}{|l|}{ Acid Production from: } \\
\hline Glucose & + & & \\
\hline Mannitol & + & + & + \\
\hline Inositol & - & + & + \\
\hline Sorbitol & + & $\mathrm{Nd}$ & - \\
\hline Rhamnose & + & $\mathrm{Nd}$ & $\mathrm{Nd}$ \\
\hline Saccharose & - & $\mathrm{Nd}$ & + \\
\hline Melibiose & - & $\mathrm{Nd}$ & + \\
\hline Amylose & - & $\mathrm{Nd}$ & $\mathrm{Nd}$ \\
\hline Arabinose & - & $\mathrm{Nd}$ & $\mathrm{Nd}$ \\
\hline
\end{tabular}

+: Positive test, -: Negative test, ND: Not Determined

Table 4: Plant growth promoting activities by Pantoea agglomerans 20-19.

\begin{tabular}{|c|c|c|c|c|}
\hline Tests & Phosphorus solubilization & Production of ammonia & Nitrogen fixation & IAA production ( $\boldsymbol{\mu g} / \mathrm{ml})$ \\
\hline Strain isolated & $55 \%$ & + & + \\
\hline
\end{tabular}

+: Positive test, -: Negative test

\section{Discussion}

The identification of this strain by the ABIS online software gave the specie Pantoea agglomerans. The analysis of the 16Sr DNA gene sequence confirmed this identification. On the basis of biochemical test and by comparing the isolated strain Pantoea agglomerans 20-19 to biochemical characteristics of type strain Pantoea agglomerans Im2 [30], two differences revealed: the urea test and Voges-Proskauer. However, the 16S rRNA sequence analysis of Pantoea agglomerans 20-19 showed 97\% similarity with Pantoea agglomerans Im2 type strain GQ 478021 [30] which has been reported as a plant associated bacterium. Hoang and Cao [31], suggested that several genera of Enterobacteriaceae such as Pantoea agglomerans were beneficial to plant. These bacteria were able to use a wide variety of cabron sources as nutrients in the rhizosphere [30].

IAA had a positive effect on root system elongation and development which helps in the uptake of water and essential nutrients. This may lead to the increased root growth and develop a healthy plant as compared to control [31-33]. In this study, Pantoea agglomerans is able to produce IAA growing in medium addition of triptophan with a value $156 \mu \mathrm{g} / \mathrm{ml}$. The production of IAA by bacteria isolated from rhizosphere had already been reported in number of studies [30,34-40].

Phosphorus (P) one of the most important nutrients, is frequently available in relatively insoluble forms considered as the limiting nutrient on plant growth and can possibly leading to phosphorus deficiency [41]. In this study, Pantoea agglomerans 20-19 showed phosphate solubilization with percentage $55 \%$ by the formation of transparent zone around the bacteria colony. Which could be due to synthesis several organic acids (phytases) [16,30,34,35,37,42].

The atmospheric N2 is converted into plantutilizable forms by biological $\mathrm{N}_{2}$ fixation which changes nitrogen to ammonia by nitrogen fixing microorganisms using a complex enzyme system 
Table 5: Overal antimicrobial susceptibility patterns of Pantoea agglomerans.

\begin{tabular}{|c|c|c|c|c|}
\hline \multirow{2}{*}{ Antibiotics } & \multicolumn{2}{|c|}{ Diamètre critiques ( $\mathrm{mm}$ ) } & \multirow{2}{*}{ Diamètre of zone $(\mathrm{mm})$} & \multirow{2}{*}{ Result } \\
\hline & $S \geq$ & $\mathbf{R}<$ & & \\
\hline AML & 19 & 19 & 27 & $S$ \\
\hline AMC & 19 & 19 & 26 & $S$ \\
\hline TIC & 23 & 20 & 24 & $S$ \\
\hline IMP & 22 & 17 & 34 & $S$ \\
\hline CFR & 12 & 12 & 18 & $S$ \\
\hline FOX & 19 & 15 & 30 & $S$ \\
\hline CRO & 25 & 20 & 8 & $\mathrm{R}$ \\
\hline CFM & 17 & 17 & 6 & $\mathrm{R}$ \\
\hline $\mathrm{CN}$ & 17 & 14 & 34 & $S$ \\
\hline AK & 18 & 15 & 32 & $S$ \\
\hline CT & 15 & 15 & 19 & $S$ \\
\hline CIP & 25 & 22 & 35 & $S$ \\
\hline NA & 14 & 14 & 19 & $S$ \\
\hline SXT & 14 & 11 & 33 & $S$ \\
\hline FOS & 14 & 14 & 10 & $\mathrm{R}$ \\
\hline
\end{tabular}

known as nitrogenase [43]. In our experiments, Pantoea agglomerans gave positive result for the nitrogen fixing activity non-nodulating by changing the green color of the medium $(\mathrm{Nfb})$ in a blue color. The utilization of halotolerant PGPR with nitrogen fixation ability is considered a good strategy to improve the growth of salt sensitive plants [44].

Another important PGP trait exhibited by the organism is ammonia production. Accumulation of ammonia in the soil also creates the alkaline conditions which suppresses the growth of certain fungi [45-48]. In this present study Pantoea agglomerans exhibted the very good ammonia production activity.

From the above results, it can be concluded that strain Pantoea agglomerans can be potentially used as bioinoculants of agricultural in a sustainable way, it requires a long way of greenhouse experiments with pot filled with different type of soils and finally, field experiements to find out the optimun formulations for the inoculums. Thus, the inoculants can perform close to its optimum potential. Future studies concerning commercialization and provisional field applications of integrated stable bio-forumulations as effective biocontrol strategies are in progress.

\section{References}

1. Li YC, Li ZW, Lin WW, Jiang YH, Weng BQ, Lin WX. Effects of biochar and sheep manure on rhizospheric soil microbial community in continuous ratooning tea orchards. Chin J Appl Ecol. 2018; 29: 1273-1282.

2. Punam K, Mukesh M, Upadhyay RS. Characterization of plant growth promoting rhizobacteria (PGPR) isolated from the rhizosphere of Vigna radiata (mung bean). Biocatalysis and Agricultural Biotechnology. 2018; 16 : 155-162.

3. Meena M, Swapnil P, Zehra A, Dubey MK, Upadhyay RS. Antagonistic assessment of Trichoderma spp. by producing volatile and non-volatile compounds against different fungal pathogens. Arch. Phytopathol. Plan Protect. 2017a; 50: 629-648.

4. Meena M, Dubey MK, Swapnil P, Zehra A, Singh S, Kumari $P$, et al. The rhizosphere microbial community and methods of its analysis, in: Singh, H.B.,
Sarma, B.K., Keswani, C. (Eds.), Advancement in PGPR Research. CABI Publishers. 2017b; 275-295

5. Meena M, Swapnil P, Zehra A, Aamir M, Dubey MK, Upadhyay RS. Beneficial microbes for disease suppression and plant growth promotion, in: Singh, D.P. Singh, H.B., Prabha, R. (Eds.), Plant-Microbe interactions in agro-ecological perspectives. Springer Nature, Singapore. 2017c; 395-432.

6. Yasmin F, Othman R and Maziz MN H. Yield and Nutrient Content of Sweet Potato in Response of Plant. Jordan Journal of Biological Sciences. 2020; 13: $117-122$

7. Hayat R, Ali S, Amara U, Khalid R, Ahmed I. Soil beneficial bacteria and their role in plant growth promotion: a review. Annals of Microbiology. 2010; 60: 579-598.

8. Babu AN, Jogaiah S, Ito S, Nagaraj AK, Tran LSP. Improvement of growth, fruit weight and early blight disease protection of tomato plants by rhizosphere bacteria is correlated with their beneficial traits and induced biosynthesis of antioxidant peroxidase and polyphenol oxidase. Plant Science. 2015; 231: 62-73.

9. Jogaiah S, Shivanna RK, Gnanaprakash PH, Hunthrike SS. Evaluation of plant growth-promoting rhizobacteria for their efficiency to promote growth and induce systemic resistance in pearl millet against downy mildew disease. Archives of Phytopathology and Plant Protection. 2010; 43: 368-378.

10. Liu W, Hou J, Wang Q, Ding L, Luo Y. Isolation and characterization of plant growth-promoting rhizobacteria and their effects on phytoremediation of petroleum-contaminated saline-alkali soil. Chemosphere. 2014; 117: 303308.

11. Liu W, Wang Q, Hou J, Tu C, Luo Y, Christie P. Whole genome analysis of halotolerant and alkalotolerant plant growth-promoting rhizobacterium Klebsiella sp. D5A. Scientific Reports. 2016; 6: 26710.

12. Sadeghi A, Karimi E, Dahaji PA, Javid MG, Dalvand Y, Askari H. Plant growth promoting activity of an auxin and siderophore producing isolate of Streptomyces under saline soil conditions. World Journal of Microbiology and Biotechnology. 2012; 28: 1503-1509.

13. Upadhyay SK, Singh JS, Saxena AK, Singh DP. Impact of PGPR inoculation on growth and antioxidant status of wheat under saline conditions. Plant Biology. 2012; 14: 605-611.

14. Chakraborty N, Ghosh R, Ghosh S, Narula K, Tayal R, Datta A, Chakraborty S. Reduction of oxalate levels in tomato fruit and consequentmetabolic remodeling following overexpression of a fungal oxalate decarboxylase. Plant Physiology. 2013; 162: 364-378.

15. Paul D, Lade H. Plant-growth-promoting rhizobacteria to improve crop growth in saline soils: a review. Agronomy for Sustainable Development. 2014; 34 : 737-752.

16. Kumar A, Prakash A, Johri B. Bacillus as PGPR in crop ecosystem. Bacteria in agrobiology: crop ecosystems: Springer. 2011; 37-59.

17. Zuffo AM, De Rezende PM, Bruzi AT, Ribeiro ABM, Zambiazzi EV, Soares $I O$, et al. Soybean cultivars agronomic performance and yield according to doses of Azospirillum brasilense applied to leaves. Australian Journal of Crop Science. 2016; 10: 579-583

18. Tonelli ML, Magallanes-Noguera C, Fabra A. Symbiotic performance and induction of systemic resistance against Cercospora sojina in soybean plants co-inoculated with Bacillus sp. CHEP5 and Bradyrhizobium japonicum E109. Archives of Microbiology. 2017; 199: 1283-1291.

19. Pawar PU, Kumbhar CT, Patil VS, Khot GG. Effect of co-inoculation of Bradyrhizobium japonicum and Pseudomonas fluorescens on growth, yield and nutrient uptake in soybean [Glycine max (L.) Merrill] Crop Research. 2018; 53: 57-62.

20. Yadav MR, Kumar R, Parihar CM, Yadav RK, Jat SL, Ram H, et al. Strategies for improving nitrogen use efficiency: a review. Agricultural Reviews. 2017; 38: $29-40$.

21. Olanrewaju OS, Glick BR, Babalola OO. Mechanisms of action of plant growth promoting bacteria. World Journal of Microbiology and Biotechnology. 2017; 33: 1-17. 
22. Yan T, Zhu J, Yang K. Leaf nitrogen and phosphorus resorption of woody species in response to climatic conditions and soil nutrients: a meta-analysis. Journal of Forestry Research. 2018; 29: 905-913.

23. Muthukumar T, Udaiyan K. Coinoculation of bioinoculants improve Acacia auriculiformis seedling growth and quality in a tropical Alfisol soil. Journal of Forestry Research. 2018; 29: 663-673.

24. Gupta A, Gopal M, Tilak KV. Mechanism of plant growth promotion by rhizobacteria. Indian J Exp Biol. 2000; 38: 856-862

25. Pikovskaya RI. Mobilization of phosphorus in soil in connection with the vital activity of some microbial species. Mikrobiologya. 1948; 17: 362-370.

26. Gothwal RK, Nigam VK, Sasmal D and P Ghosh. Phosphate solubilization by rhizospheric bacterial isolates from economically important desert plants. Indian J Microbiol. 2006: 355-361.

27. Loper JE, Scroth MN. Influence of Bacterial Sources of Indole-3- acetic Acid on Root Elongation of Sugar Beet. 1986; 76: 386-389.

28. Cappuccino JC, Sherman N. Microbiology. In: A Laboratory Manual (Eds.: rd). Newyork, Benjamin/cummings Pub. Co. 1992: 125-179.

29. Rajasankar $R$ and Ramalingam $C$. In vitro screening of saccharum officinarum L. rhizophere bacteria for plant growth promotion traits," International Journal of Advanced Life Sciences. 2012; 1: 40-49.

30. Silini-Cherif H, A Silini, M Ghoul and S Yadav. Isolation and Characterization of Plant Growth Promoting Traits of a Rhizobacteria: Pantoea agglomerans Ima2. Pakistan Journal of Biological Sciences. 2012; 15: 267-276.

31. Hoang MT, and Cao ND. Isolation, characterization and identification of endophytic bacteria in sugarcane (Saccharum spp. L.) cultivated on soils of the Dong Nai province, Southeast of Vietnam. American Journal of Life Sciences. 2014; 2: 361-368

32. Etesami H, Hossein AA, Abolfazl AA. Evaluation of plant growth hormones production (IAA) ability by Iranian soils, rhizobial strains and effects of superior strains application on wheat growth indexes. World Appl Sci J. 2009 6: 1576-1584.

33. Glick BR. The enhancement of plant growth by free living bacteria. Can $J$ Microbiol. 1995; 41: 109-114.

34. Saengsanga T. Isolation and Characterization of Indigenous Plant GrowthPromoting Rhizobacteria and Their Effects on Growth at the Early Stage of Thai Jasmine Rice (Oryza sativa L. KDML105), Arabian Journal for Science and Engineering. 2018; 43: 3359-3369.

35. Moustaine M, El Kahkahi R, Benbouazza A, Benkirane R, Achbani EH. Effect of plant growth promoting rhizobacterial (PGPR) inoculation on growth in tomato (Solanum Lycopersicum L.) and characterization for direct PGP abilities in Morocco. International Journal of Environment, Agriculture and Biotechnology. 2017; 2: 590-596.

36. Majumdar S and Chakraborty U. Phosphate Solubilizing Rhizospheric
Pantoea agglomerans Acti-3 Promotes Growth in Jute Plants, World Journal of Agricultural Sciences. 2015; 11: 401-410.

37. Ekinci M, Turan M, Yildirim E, Güneú A, Kotan R, Dursun A. Effect of plan growth promoting rhizobacteria on growth, nutrient, organic acid, amino acid and hormone content of cauliflower (Brassica oleracea L.var. botrytis) transplants. Acta Sci. Pol., Hortorum Cultus. 2014; 13: 71-85.

38. Sudha, M, RS Gowri, P Prabhavathi, P Astapriya SY Devi and A Saranya Production and optimization of indole acetic acid by indigenous micro flora using agro waste as substrate. Pak. J. Biol. Sci. 2012; 15: 39-43.

39. Dastager SG, CK Deepa, SC Puneet, CS Nautiyal and Pandey A. Isolation and characterization of plant growth-promoting strain Pantoea NII-186. From Western Ghat Forest soil, India. Lett. Appl. Microbiol. 2009; 49: 20-25.

40. Cimmino A, A Andolfi, G March, G Surico and A Evidente. Phytohormone production by strains of Pantoea agglomerans from knots on olive plants caused by Pseudomonas savastanoi pv. savastanoi. Phytopathol. Mediterr. 2006; 45: 247-252.

41. Khan MS, Zaidi A, Ahmad E. Mechanism of phosphate solubilization and physiological functions of phosphate-solubilizing microorganisms. In:Khan,M.S., Zaidi,A.,Musarrat, J.(eds.) Phosphate Solubilizing Microorganisms: Principle and Application of Microphos Technology. 2014: 31-62.

42. Rana A, Saharan B, Joshi M, Prasanna R, Kumar K, Nain L. Identification of multi-trait PGPR isolates and evaluating their potential as inoculants for wheat. Ann. Microbiol. 2011.

43. Kim $\mathrm{J}$ and DC Rees. Nitrogenase and biological nitrogen fixation, Biochemistry. 1994; 33: 389-397.

44. Etesami $H$ and Beattie GA, Mining halophytes for plant growth-promoting halotolerant bacteria to enhance the salinity tolerance of non-halophytic crops. Front. Microbiol. 2018; 9: 148.

45. Jha CK, Patel B, Sarf M. Stimulation of the growth of Jatropha curcas by the plant growth bacterium Enterobacter cancerogenus MSA2. World J Microbiol Biotechnol. 2012; 28: 891-899.

46. El Kahkahi R, Moustaine M, Channaoui S, Hafidi M, Zouhair R, Ait Chitt M, et al. Characterization of plant growth promoting rhizobacteria isolated from the rhizosphere of carob tree (Ceratonia siliqua L.) in Morocco. Eurasia J Biosci. 2019; 13: 921-930

47. Loch TP and Faisal M. Isolation of Pantoea agglomerans from Brown Trout (Salmo trutta) from Gilchrist Creek, Michigan, USA. Bull.Eur.Ass.Fish Pathol. 2007; 27: 200-204

48. Ryu R, Patten CL. Aromatic amino acid-dependent expression of indole-3pyruvate decarboxylase is regulated by $4 \mathrm{TyrR}$ in Enterobacter cloacae UW5. American Society for Microbiology. 2008; 190: 1-35 